\title{
Effect of Methods of Hydrolysis on the Composition of Prosopis Africana seed Hydrolysates
}

\author{
Onah, AI and Okore, VC \\ Department of Pharmaceutics, Faculty of Pharmaceutical Sciences, University of Nigeria, Nsukka, Enugu \\ State, Nigeria.
}

\begin{abstract}
Variations in plant or animal species, climatic conditions as well as processing methods affects the reproducibility, quality and quantity of natural or industrial raw materials. In the present study, Prosopis africana seed was hydrolysed using two distinct methods. In a separate study, the hydrolysates were found to be good sources of peptone for microbial cultures. The proximate analyses of contents of hydrolysates obtained from enzyme-hydrolysed or acid-hydrolysed seeds were determined. The seeds obtained from a local market were thoroughly cleaned and boiled until the seed coats were softened. The softened seed coats were manually removed to reveal the cotyledons, which were washed, dried and powdered. The powdered cotyledon was subjected to hydrolysis using the enzyme, papain, or hydrochloric acid. Proximate analysis of the hydrolysates was determined using standard methods. The results revealed that papain-hydrolysed seeds (PHP) and acidhydrolysed seeds (AHP) had moisture contents of $32.7 \%$ and $83.3 \%$, respectively whereas the ash values were $3.05 \%$ and $0.15 \%$. Protein contents of PHP and AHP were $39.69 \%$ and $12.78 \%$ respectively. Crude fibre compositions were $2.01 \%$ in PHP while AHP showed no presence of fibre. It was observed that methods of hydrolysis significantly affected the quality of Prosopis africana seed hydrolysates.
\end{abstract}

Keywords: Prosopis africana seed hydrolysates, papain, Hydrochloric acid.

\section{Introduction}

Prosopis africana is a perennial leguminous tree of the family Mimosidea that is mostly found growing in the savanna region of West Africa [1]. In Nigeria, the seeds are very important to the Idoma, Ighala, Ebira and Tiv people who use them to prepare fermented soup condiment known as "ukpehe" which is rich in protein and fatty acids [2]. Related studies have further reported that Prosopis africana seeds also contain carbohydrate, crude fibre, mineral elements as well as vitamins [3]. Seeds of high nutritional value of this nature can be useful in developing industrial raw materials that will have vast array of application in human and animal nutrition, pharmaceutical and biotechnological industries. One of the most popular methods of processing this leguminous seeds is fermentation using microbial enzymes [4]. However, utilization of chemical or protease in the hydrolysis of this proteinous plant product could be useful in standardization of the optimum method of processing this seed for industrial uses. Hydrolysis of plants or animal materials of the same source using different methods can greatly affect the quality and quantity of product outcome. It is therefore the aim of this study to compare the effects of acid or papain (enzyme) methods of hydrolysis of Prosopis africana seed using the proximate analysis as the assessing criteria.

\section{Sample preparation}

\section{Materials And Methods}

Prosopis africana seeds were purchased from a local market in Nigeria. The seeds were sorted to remove solid contaminants, and decaying seeds. The selected seeds were washed in de-ionized water and then boiled for 8 hours until the seed coats became soft and swollen. The seed coats were manually peeled off leaving behind the clean cotyledons. The cleaned cotyledons were dried in an oven at $40^{\circ} \mathrm{C}$ for 12 hours, weighed and pulverized using a Kenwood blender. The resulting powder was kept in an air-tight container and stored at $4^{\circ} \mathrm{C}$ prior to further procedures.

\section{Acid hydrolysis}

Two hundred grams of the Prosopis africana seed flour was soaked in $250 \mathrm{ml}$ of $6 \mathrm{M} \mathrm{HCl}$. The mixture was incubated at $80^{\circ} \mathrm{C}$ for 24 hours. At the end of the incubation period, the broth was diluted with $500 \mathrm{ml}$ of de-ionized water and then boiled at $100^{\circ} \mathrm{C}$ for 1 hour. The solution was then cooled to room temperature, and the $\mathrm{pH}$ adjusted to 7.0 with $6 \mathrm{M} \mathrm{NaOH}$. The mixture was filtered through Whatman's No.1 filter paper. The filtrate was lyophilized using a freeze-dryer (Amsco/Finn-Aqua Lyovac GT3, Germany) to yield acid-hydrolysate of Prosopis africana seed (AHP). 


\section{Papain hydrolysis}

Two hundred grams of powdered Prosopis africana seed was weighed and suspended in $800 \mathrm{ml}$ of distilled water. This was stirred to form slurry. The $\mathrm{pH}$ of the slurry was adjusted to 6.5 with $1 \mathrm{M} \mathrm{HCl}$. Commercially obtained papain (BDH Chemical Ltd, Pools, England) was added to the slurry to make a concentration of $0.25 \%$. Digestion was allowed to take place for 9 hours at a temperature of $60{ }^{\circ} \mathrm{C}$, and the $\mathrm{pH}$ was controlled using $1 \mathrm{M} \mathrm{NaOH}$. The temperature was then raised to $80^{\circ} \mathrm{C}$ for 15 minutes to inactivate the enzyme. Liquor from the hydrolysed material was separated from the protein/enzyme slurry by repeated centrifugation. The clear solution was then freeze-dried to obtain papain-hydrolysate of Prosopis africana seed (PHP).

\section{Proximate analysis \\ Moisture content}

The standard method of the Association of Official Analytical Chemists [5] no. 925.10, using hot air oven was adopted. Three porcelain dishes were thoroughly washed and dried in a hot air oven at $100{ }^{\circ} \mathrm{C}$ for 30 minutes. They were cooled in a desiccator to ensure absence of surface moisture. The dishes were then weighed, and 2 grams of the sample were placed in each of them and heated in an oven set at $105{ }^{\circ} \mathrm{C}$ for six hours. The containers were removed from the oven and cooled in the desiccator, to prevent moisture re-absorption. After cooling, the porcelain dishes were weighed again until constant weights were obtained and the percentage moisture content was calculated as follows:

$\%$ Moisture content $=\frac{(X-Y)}{\mathrm{Z}} \times \frac{100}{1}$-where $\mathrm{X}=$ Sum of weight in gram of each of the dishes and sample before drying; $\mathrm{Y}=$ Weight in gram of the dish and sample after drying and $\mathrm{Z}=$ Initial weight of the sample in grams.

\section{Determination of ash value}

The ashing crucibles were washed and dried in a hot air oven at $100{ }^{\circ} \mathrm{C}$ for 25 minutes. They were then cooled in desiccators and weighed. Two grams of dry samples were each placed in the porcelain crucibles and transfered into a muffle furnace set at $600^{\circ} \mathrm{C}$. The material was burnt until ashing was completed. The crucibles and contents were then cooled in the desiccators, and reweighed [5].

Percentage ash was calculated as follows:

$\%$ Ash $=\frac{\text { Weight of Ash }}{\text { Weight of Sample }} \times \frac{100}{1}-$

\section{Determination of lipid content}

Two grams of the sample were placed in a weighed thimble and introduced into a dry Soxhlet column attached to a weighed extraction flask containing $100 \mathrm{ml}$ of petroleum ether. Extraction was continued until the refluxing liquid became colourless. The thimble and its content were removed from the chamber, cooled in desiccators and re-weighed [5]. The percentage of fats for each sample was obtained, as:

$$
\% \text { Fat }=\frac{X-Y}{Z} \times \frac{100}{1}
$$

where $\mathrm{X}=$ Weight of thimble and sample before extraction $(\mathrm{g}) ; \mathrm{Y}=$ Weight of thimble and sample after extraction $(\mathrm{g})$ and $\mathrm{Z}=$ Weight of the sample $(\mathrm{g})$.

\section{Determination of total protein}

The micro-Kjedahl method described by [5] was used in the determination of the total crude protein. This involves three stages:

(a) Digestion: $10 \mathrm{~g}$ of each sample was digested with a mixture of concentrated sulphuric acid; a pinch each of copper sulphate and sodium sulphate crystals, to act as catalysts, were added. The mixtures were heated till the black liquid cleared. Heating was continued till the sample became completely digested. The digested samples were transferred into a $100 \mathrm{ml}$ volumetric flask and the volume made up to the mark with distilled water.

(b) Distillation: Kjedahl distillation apparatus was used. Ten ml of $4 \%$ boric acid was combined with two drops each of methyl blue and methyl red indictors in $100 \mathrm{ml}$ conical flask. The conical flask was positioned at the receiving side of the distillation unit using a clamp. Five milliliters $(5 \mathrm{ml})$ of the digested samples were first introduced into the distillation unit followed by addition of $10 \mathrm{ml}$ of $50 \%, \mathrm{NaOH}$ gradually. The distillation process lasted between five to ten minutes, during which ammonia $\left(\mathrm{NH}_{3}\right)$ was trapped in excess boric acid. The presence of ammonia changed the purple colour of boric acid to green, which is a common characteristic of alkaline gases.

(c) Titration: Fifty $\mathrm{ml}$ of the distillate was titrated against $0.01 \mathrm{M} \mathrm{HCl}$ after which crude protein content of the samples was calculated by the formula: 


$$
\% \text { Nitrogen }=\frac{\text { Titre } \times 0.01 \times \text { DF } \times \text { MWN }}{\text { Weight of sample }(\mathrm{g})} \times \frac{100}{1}
$$

where $\mathrm{DF}=$ dilution factor $(100 \mathrm{ml} / 5 \mathrm{ml})=20$; and $\mathrm{MWN}=$ Molecular weight of nitrogen $=14.01 ; \%$ Total Protein $=\%$ nitrogen $\times 6.25$.

\section{Determination of crude fibre content}

Two grams of sample was hydrolysed in a beaker with $200 \mathrm{ml}$ of near-boiling $1.25 \%$ of sulphuric acid $\left(\mathrm{H}_{2} \mathrm{SO}_{4}\right)$ for 30 minutes. The content was filtered under suction, washed with $40-50 \mathrm{ml}$ portion of near boiling water and was boiled for 30 minutes with $200 \mathrm{ml}$ of $1.25 \% \mathrm{NaOH}$. The digest was washed with $25-30 \mathrm{ml}$ portion of near-boiling $1.25 \% \mathrm{H}_{2} \mathrm{SO}_{4}$ and then washed with $25-30 \mathrm{ml}$ portion near-boiling water and filtered. The residue was collected and put into weighed crucible and dried at $130{ }^{\circ} \mathrm{C}$ for 2 hours. The crucible plus the residue were cooled in a desiccator and re-weighed. The dried digest was ashed in a muffle furnace at $550{ }^{\circ} \mathrm{C}$ for 5 hours [5]. The ash was cooled, weighed and the percentage crude fibre was calculated as follows.

$$
\% \text { Crude fibre }=\frac{\text { Weight after drying }- \text { weight after ignition }}{\text { Weight of sample }(\mathrm{g})} \times \frac{100}{1}
$$

\section{Determination of total carbohydrate}

Two hundred milligram $(200 \mathrm{mg})$ of the sample was mixed with $50 \mathrm{ml}$ of boiling distilled water in a beaker. Three mililitres $(3 \mathrm{ml})$ of $5 \mathrm{M}$ hydrochloric acid was added and the mixture boiled for 30 minutes. The content of the flask was allowed to cool and was neutralized with $5 \mathrm{M} \mathrm{NaOH}$ solution. The hydrolysate was then transferred into a $100 \mathrm{ml}$ volumetric flask and the volume made up to $100 \mathrm{ml}$ with distilled water. Using 10 fold serial dilutions, $0.2 \mathrm{ml}$ of the solution was pipetted and made up to $2 \mathrm{ml}$ with distilled water for spectrophotometric determination of $512 \mathrm{~nm}$ [7].

$\%$ Total carbohydrate $=\mathrm{mg}$ of glucose equivalent to sample absorbance from graph $\times$ conversion factors (25) $\times$ dilution factor

\section{Results}

\begin{tabular}{|c|c|c|c|c|c|c|}
\hline \multirow[b]{2}{*}{ Media } & \multicolumn{5}{|c|}{ Composition in $\mathrm{g} / 100 \mathrm{~g}$} & \multirow{2}{*}{ Ash } \\
\hline & Moisture & Crude protein & Fat & Total carbohydrate & Crude fibre & \\
\hline PHP & $32.70 \pm 0.01$ & $39.69 \pm 0.001$ & $8.68 \pm 0.002$ & $16.97 \pm 0.01$ & $2.01 \pm 0.01$ & $3.05 \pm 0.01$ \\
\hline $\mathrm{AHP}$ & $83.30 \pm 0.03$ & $12.78 \pm 0.01$ & $1.02 \pm 0.003$ & $2.98 \pm 0.04$ & $0.00 \pm 0.00$ & $0.15 \pm 0.01$ \\
\hline
\end{tabular}

Table 1: Proximate composition of PHP and AHP

PHP: Papain hydrolysed Prosopis africana seed

AHP: Acid hydrolysed Prosopis africana seed

\section{Discussion}

In the proximate composition of Prosopis africana seed as reported by [7], a percentage moisture of $1.9 \pm 0.03 \%$ was recorded and adjudged low though comparable to rear cowpea $(1.8 \pm 0.25 \%)$, cranberry bean $(1.7 \pm 0.51 \%)$ and kersting's groundnut $(1.7 \pm 0.12 \%)$. They further opined that the value of $1.9 \pm 0.03 \%$ was within the range expected of most legumes and that the low moisture content will afford a long shelf life for Prosopis africana [7]. On the contrary, the moisture content obtained in the proximate composition of fermenting Prosopis africana cotyledons in the laboratory into okpehe by Ogunshe [8] were between $68.0 \%$ on the first day of fermentation and $72.8 \%$ after the fifth day of fermentation. The moisture content of 40.7-60.0\% was recorded in ukpehe sample from market sources [9].

In the present study, the moisture content of $32.7 \%$ and $83.3 \%$ for PHP and AHP respectively were obtained. Such moisture as obtained in this Prosopis africana seed hydrolysate can afford organisms free-water (water that is not bound in its complex structures and can provide enabling environment for the transfer of nutrients and toxic waste). This "free" water however can result in material degradation and as such need to be adequately evaporated or dried for proper preservation of the hydrolysate prior to use.

The crude fibre of $2.1 \%$ for PHP is low compared to $3.3 \%$ obtained by [10] where he recorded. Crude fibre of $3.3 \%$ was obtained in proximate composition of Prosopis africana flour [7]. Crude fibre was, however, not detected in the acid hydrolysate of the Prosopis africana seed. This is an indication that different methods of hydrolysis can affect a product or products from same source. It is very possible that, in the course of hydrolysis, the harsh attack of acids on the polymeric structure of the hydrolysate may have led to the loss of crude fibre in the final product. Enzyme hydrolysis of both PHPs could be the reason crude fibre was detected in sample. There is evidence that dietary fibre has a number of beneficial effects. Some soluble fibre which dissolve in water are readily fermented in the colon into gases and physiologically active by-products which can 
be prebiotics. Table 1 reveals fat content of $8.6 \%$ and $1.02 \%$ for PHPs and AHPs respectively. In food and other related industries where rancidity is a threat to product stability, exploration of enzymatic hydrolysis portends high risk. Therefore, it becomes imperative that Prosopis africana seeds should be completely defatted prior to processing of the final product(s). Ash as one of the components in proximate analysis of Prosopis africana seed hydrolysate consists mainly of salty, inorganic constituents. Ash values of $3.05 \%$ in PHP and $0.15 \%$ in AHP, clearly depicts reasonable availability of mineral elements in the hydrolysates. These values are slightly lower than 5.01-7.07 \% recorded by [3] and $4.4 \%$ as was obtained by [7]. Lower value of $0.15 \%$ recorded in AHP negates the expectation that neutralization reaction could produce more salts. Protein hydrolysates are major sources of nitrogen and vitamins in microbiological media. In the analysis of fermenting Prosopis africana seed, [4]observed high proteinase activity which was attributed, in part, to the high protein content of the seeds. Protein in Prosopis africana seeds constitutes about $60 \%$ or more of the seed kernel's weight [11]. In the present study, papain hydrolysate recorded crude protein value of $39.69 \%$ which was higher than the values estimated from percentage nitrogen calculated from micro-Kjedahl as documented in the above cited works. This depicts its high potential as source of nitrogen, amino acid and other protein derivatives in animal feeds as well as biochemical industries. This value obtained from the enzyme digest of Prosopis africana seed also compares favourably well with the results of [12] obtained in soybean $47.73 \%$ and African locust bean $30.69 \%$ while exploring the possibility of developing peptone from enzyme hydrolysis of soya beans and African locust bean. On the contrary, the value of $12.78 \%$ for AHP was low relative to PHP. This can be attributed to the effect of acid in breaking some peptide bonds and, in the process some amino acids are lost in forms of soluble salts and are not detected. From this study, it can be seen that enzyme digest of same or similar plants or animal product yields higher protein values than similar results obtained from estimation or acid hydrolysis. The ability of a raw material to provide readily available and easily metabolizable carbohydrate to furnish the cellular energy needs in biotechnological exploration is indispensable. In this study, total carbohydrate value of $34.33 \%$ was recorded for PHP. Ajiboye et al., [10] recorded $1.9 \%$, while Gberikon et al., [3] had 26.01-28.17\%. Reduction of carbohydrate to more soluble components like glucose in part, explains the lower value recorded in AHP. Similarly, other related researches [13] obtained lower values for their acid hydrolysates. Therefore, methods employed in the processing of similar plant or animal raw materials determine to a reasonable extent the product outcome.

\section{Conclusion}

Adequate knowledge guided by informed choice of industrial processes greatly determines the outcome of the quality and quantity of finished products. Acid method of hydrolysis is a harsh process and as such could lead to loss of certain essential ingredients in raw materials. The enzyme, papain, exhibited protein sparing effect as shown in the proximate composition of the hydrolysates. This is essential in bio pharmaceutical industries where amino acids and other protein derivative are manipulated and modified into useful products. This work has successfully provided base-line information for further research on this plant seeds hydrolysates.

\section{Reference}

[1]. Keay RWJ, Onochie CFA and Stanfield DP 1964. The Nigeria tree, Vol II. Federal Forestry Research, Ibadan, Nigeria, pp 113-114.

[2]. Sanni AE and Lindberg AM. 1993. Fatty acid composition of Prosopis africana and its fermented products

[3]. "Okpehe".Food Chemistry Microbiology Technology 15: 89-90

[4]. Gberikon GM., Agbulu CO and Yaji ME. 2015. Nutritional composition of fermented Prosopis africana soup condiment with and without inocula. International Journal of Current Microbiology and Applied Sciences 4(2): 166-171.

[5]. Adenike AOO, Mopelola O and Ayansina ADV. 2007. Microbial studies and Biochemical characteristics of controlled fermented Afiyo- a Nigerian fermented Food Condiment from Prosopis africana (Gull and Perr.) Taub. Park Journal of Nutrition 6:620-627.

[6]. Association of Official and Analytical Chemist. 2010. Official method of analysis: A.O.A.C. Washington D.C

[7]. Pearson D. 1976. Laboratory techniques in food analysis. Butterworth and Co. Ltd.

Aremu MO, Olonisakin A., Atolaye BO and Ogbu CFJ. 2006. Some nutritional and functional studies of Prosopis africana. Electronic J. Environ. Agric. Food Chem., 5:1640-1684.

[8]. Ogunshe AAO. 1989. Proximate composition of fermenting P. africana cotyledons. B.Sc. Dissertation. Department of Botany Microbiology, University of Ibadan, Nigeria

[9]. Oguntoyinbo FA, Onilude AA and Sanni AI. 2001. Micro flora and proximate composition of okpehe, a fermented condiment from Prosopis africana seeds. Adv. Food Sci., 165-170.

[10]. Ajiboye AA, Agboola DA, Fadium OY and Afolabi AO 2003.Antimicrobial, phytochemical and proximate analysis of Prosopis afri cana seed and extract. FUTA Journal of Research in Sciences (1):101-109.

[11]. Safari R, Motamedzadegen, A, Ovissipour M, Regenstein, JM, Gildberg A, and Rasco B. 2009.Use of hydrolysates from yellow fin tuna (Thunnus albacares) heads as a complex nitrogen source for lactic acid bacteria. Food Bioprocess Chemistry 115:238-242.

[12]. Uzeh RE, Akinola SO and Olatope. 2006. Production of peptone from soybeans Glycine Max L merr) and

[13]. African locust beans (Parkia biglobosa). African Journal of Biotechnology 5(18):1684-1686.

[14]. Nicharee W and Sasithorn K. 2015. Production of fish Protein hydrolysates by acid and enzymatic hydrolysis. Journal of Medical a nd Bioengineering 4 (6):446-470 